\title{
Recent changes in the presence status and numbers of ruddy shelduck (Tadorna ferruginea) in the Eastern Balkans
}

\author{
Peter Shurulinkov $^{1}$, Girgina Daskalova ${ }^{12}$, Konstantin Popov ${ }^{3}$, Svetla Dalakchieva ${ }^{4}$, \\ Rossen Tzonev ${ }^{5}$, Ivaylo Dimchev ${ }^{6}$, Andrey Ralev ${ }^{7}$
}

1 National Museum of Natural History, Bulgarian Academy of Sciences, 1 Tsar Osvoboditel Blvd, 1000 Sofia, Bulgaria, e-mail: p.shurulinkov@gmail.com

2 Bulgarian Society for Protection of Birds, Yavorov Complex, 1111 Sofia, Bulgaria, e-mail: girginand@gmail.com

3 One Nature Society, Burgas, Bulgaria, e-mail: office@onenat.org

4 Department of Ecology and Environmental Protection, Burgas University "Prof. Dr Asen Zlatarov", 1 Prof. Yakimov Street, Burgas, Bulgaria, e-mail: s.dalakchieva@gmail.com

5 Faculty of Biology, Sofia University, 8 Dragan Tzankov Street, 1164 Sofia, Bulgaria, e-mail: rossentzonev@abv.bg

6 Institute of Biodiversity and Ecosystem Research, Bulgarian Academy of Sciences, 1 Tsar Osvoboditel Blvd, 1000 Sofia, Bulgaria, e-mail: ivo178@abv.bg

7 Balkani Wildlife Society, Sofia, 8 Dragan Tzankov Street, 1164 Sofia, Bulgaria, e-mail: alibotush@gmail.com

\begin{abstract}
The ruddy shelduck (Tadorna ferruginea) is a species of great conservation importance within its European breeding grounds. Tadorna ferruginea is included in the Red Data Book of Bulgaria (2015) in the category "Critically Endangered". The species is qualified as "Near Threatened" in EU27 countries as a whole. Recent data from the Balkan parts of the species range indicate its considerable enlargement. During the last 10-year period, the presence status of the ruddy shelduck during winter changed from incidentally wintering in low numbers to regular and even locally abundant wintering species. The numbers of T. ferruginea migrating over the Eastern Balkans increased substantially, especially during autumn. The reasons of these expansion of the species are discussed.
\end{abstract}

Keywords: Balkan Peninsula, distribution, migration, population increase, ruddy shelduck, winter numbers

\section{Introduction}

The ruddy shelduck (Tadorna ferruginea Pallas, 1764) has a small natural breeding range in Europe, restricted to the southernmost parts of Russia and Ukraine, Southern Moldova, eastern parts of Romania (Dobroudzha), Bulgaria, Greece and European Turkey (Nankinov et al., 1997; Hagemejer \& Blair, 1997; Birdlife International, 2004). It is a species of great conservation importance in its European breeding grounds and is included in the Red Data Book of Bulgaria in the category "Critically Endangered" (Zehtin- djiev et al., 2015).The species is qualified as "Near Threatened" in EU27 countries (Birdlife International, 2015). Tadorna ferruginea was considered as a breeding migratory species in Bulgaria, wintering in the country as an exception (Zehtindjiev et al., 2015). A steady decrease in population numbers for the period 1990-2010 was reported: from 50-200 breeding pairs (Kostadinova, 1997) to 70-90 pairs (Nankinov et al., 2004), 40-80 pairs (Ilieva et al., 2007) and further to only 15-20 pairs (Zehtindjiev et al., 2015). During the last 20 years a program for restocking of the local population was implemented at the Biological Experimental Station Kalimok (Institute of Biodiversity 
and Ecosystem Research of the Bulgarian Academy of Sciences), in an attempt to stop the negative trends in numbers of this species.

In Greece, a small nesting population of the species is confined to NE Thrace and some of the Aegean Islands, with a total of 15-40 breeding pairs in the 90-ties of the XX-th century (Handrinos \& Akriotis, 1997; Birdlife International, 2004).

In Romania, the ruddy shelduck is breeding almost entirely in the easternmost district of Dobroudzha (Dobrogea) (http://pasaridinromania.sor.ro/Califar-rosu).

Typical wintering grounds of the species in the western parts of its distribution lie in Turkey, Syria, Palestine, North Egypt, Iraq, Iran, Azerbajdzjan (Hue \& Etchecopar, 1970; Cramp \& Simmons, 1977). The ruddy shelduck is a migratory bird on the Balkan Peninsula with small numbers wintering in Greece (Cramp \& Simmons, 1977). Winter numbers recorded during the mid-winter counts of waterfowl in Bulgaria have been in the range of $0-15$ individuals (Kostadinova, 1997). According to Michev \& Profirov (2003), in the period 1977-1996 only five ruddy shelducks have been recorded to winter in the country during these counts. The same authors mention the first more numerous flock wintering in Bulgaria: 16 individuals (ind.) has been recorded in January, 1999 in the Danube River between Ruse and Silistra. A flock of 14 ind. was observed in the Durankulak Lake, NE Bulgaria, on 29.12.2006 (Simeon Gigov - https://ebird. org/view/checklist/S35057644).

In Greece, the species winters regularly but in low numbers (Bauer et al., 1969; Handrinos \& Akriotis, 1997). Occasionally, bigger flocks of tens of birds have been recorded during winter and migration periods, mainly in the coastline lakes of Thrace: in the delta of the Mesta (Nestos) River - up to 150 ind. on 15.01.1973, in the delta of the Maritsa (Evros) Riverup to 68 ind, in the Ismaris Lake - up to 25 ind. (Handrinos \& Akriotis, 1997).

Migration of the species over the Eastern Balkans during the 90-ties of XX-th century was considered as "almost unnoticeable" and took place in spring from the end of February until April and in autumn - from the end of July to November (Nankinov et al., 1997).

New data collected for the present study, including terrain observations and literature sources, reveal considerable changes in status, distribution and numbers of the ruddy shelduck in the Balkan countries during the last ten years.

\section{Material and methods}

The study area included the major part of the Balkan distribution of the ruddy shelduck - Bulgaria, the easternmost part of Romania and continental Greece (the Aegean coast of the Thrace Province).

The data were collected during the period 20082020. Data on the status and distribution of the ruddy shelduck in the Balkan countries before 2008 had already been presented in the existing scientific literature (Nankinov et al., 1997; Handrinos \& Akriotis, 1997; Ilieva et al., 2007; Zehtindjiev et al., 2015). Out of 30 formerly known localities, 20 were visited on one or more occasions during the period of the present study.

Inland wetlands were specifically investigated during the breeding period of the species - AprilJune. We chose wetlands offering typical habitat for the species, i.e. small- to medium- sized artificial or natural wetlands among steppes, natural grasslands or agricultural lands with bare shores and suitable places for earth or rock hollows in the vicinity (e.g. limestone or loess slopes or cliffs, often along small rivers or in dry river valleys). All types of wetlands were visited during migration and winter periods.

\section{Results}

\section{Breeding distribution}

\section{Bulgaria}

During the period of the study, a considerable enlargement of the breeding distribution of the ruddy shelduck in Bulgaria was recorded (Fig. 1). We found that the occupied territory in North-eastern Bulgaria was enlarged in southern direction. In South-eastern Bulgaria the newly found localities lay in western and south-western direction from the previously known distribution. Concrete new localities were as follows:

- North-eastern Bulgaria

- in a reservoir to the east of Tranitsa Village, Shumen District (UTM square NJ21) - on 22.05.2010, a pair was observed leading 11 pulli, still not feathered. At the same locality, the species was present also during the breeding period of 2011 - observations on 20.04, 22 ind. and 27.05 -48 ind. (Daniel Mitev, in ebird.org); 
Recent changes in the presence status and numbers of ruddy shelduck (Tadorna ferruginea) in the Eastern Balkans

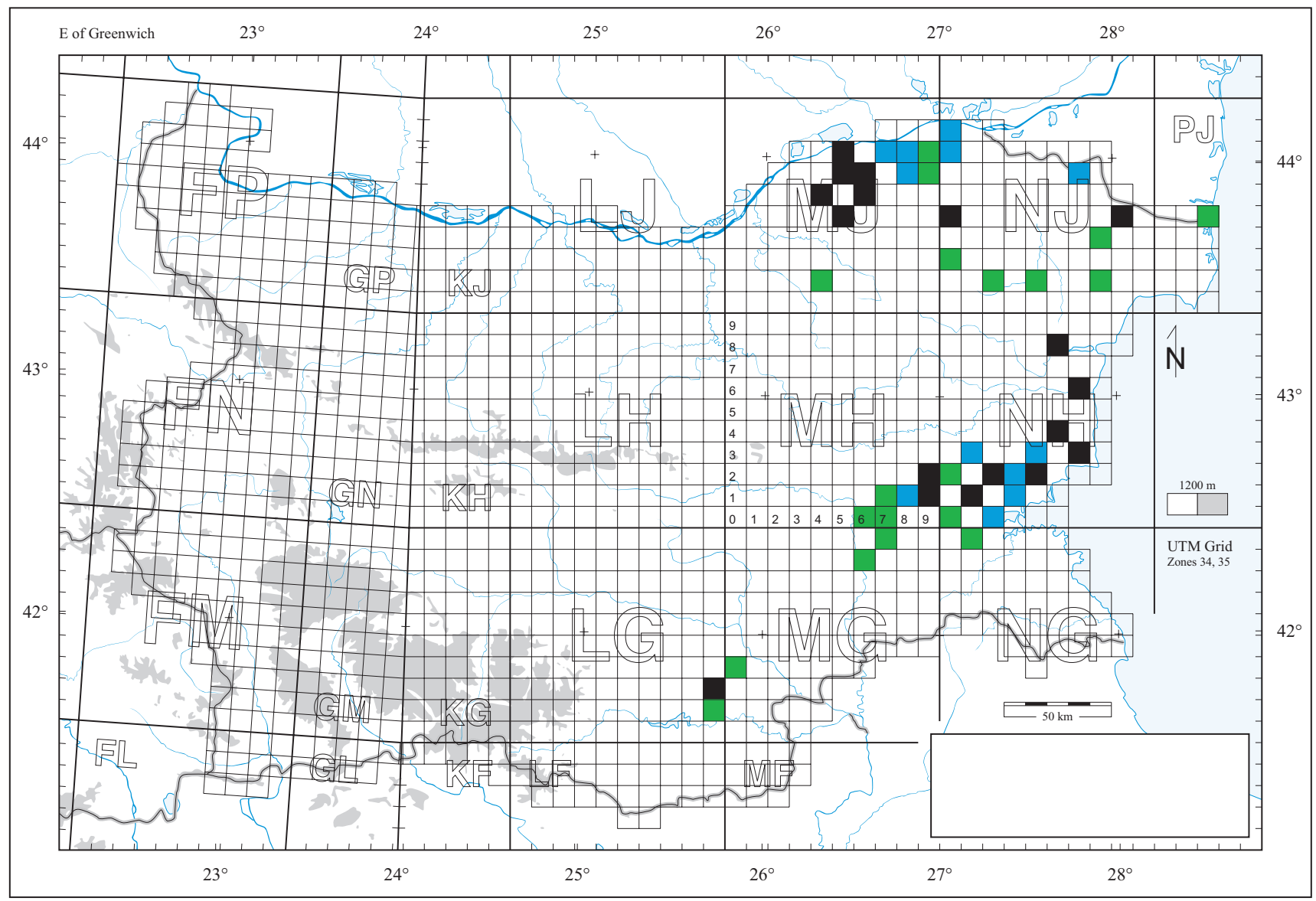

Fig. 1. Recent enlargement of the breeding distribution of the ruddy shelduck (Tadorna ferruginea) in Bulgaria. Black squares - localities recorded in the period 1995-2007 (according to Ilieva et al., 2007; Zehtindjiev et al., 2015 and personal observations of the authors) but not confirmed later; Blue squares - localities recorded in the period 1995-2007 and proved again later; Green squares - new localities, 2008-2019. Cases of proved breeding and probable breeding of the species combined.

- in a small reservoir at Lyatno Village, Shumen District (UTM NJ02) - 30.05.2011, one pair;

- in Fiseka Reservoir, Shumen District (UTM square MH79) - 1.05.2019, one pair (Simeon Gigov, in ebird.org);

- in a small reservoir "Karamandere", between Zvanets and Strahil Villages, Varna District (UTM square NJ41) - 14.04.2010, one adult ex.; 23.05.2010, one adult ex.;

- in Botevo Reservoir, Varna District (UTM square - NJ50) - June, 2008, three ex. (Sue Wright, in ebird.org);

- Chairya flooded pastures, at General Kolevo Village, Dobrich District (UTM square NJ73) 23.05.2010, four adults (Shurulinkov et al. 2013);

- Chairharman flooded area, between Bezvoditsa and Odartsi Villages, Dobrich District (UTM square - NJ71) - 6.06.2010, two pairs (Shurulinkov et al. 2013);

- NE of Durankulak Village, at "Sveta Anna" beach, Dobrich District (UTM square PJ24) 23.06.2017, one pair. Along that beach, there was a high earth cliff with suitable holes for breeding of the ruddy shelduck;

— "Lomtsi" Reservoir, SW of Lomtsi Village, Targovishte District (UTM square MJ41) - 29.05.2011, one adult ex.;

- reservoir at Nova Popina Village (UTM square MJ41) - one breeding pair in 2012 (Shurulinkov et al., 2019).

- South-eastern Bulgaria (Thracian Plain)

- Asenovo Reservoir at Asenovo Village, Yambol District (UTM square MG79) - 4.04.2009, 
one pair; May, 2012, one pair with ten pulli; 26.05.2019, one pair with seven pilli (Daskalova et al., in print);

- Tundzha River at Tenevo Village, Tundzha Municipality, Yambol District (UTM square MG68) 21.03.2006, one pair; 3.04.2016, one pair (Daskalova et al., in print);

- reservoir between Charda and Mogila Villages, Yambol District (UTM square MH60) 19.04.2009, one pair (Daskalova et al., in print);

- reservoir to the north of Tarnava Village, Yambol District (UTM square MH70) - 19.04.2009, one pair (Daskalova et al., in print);

- Atolovo, Yambol District (UTM square MH71) - 18.04.2010, one pair; 13.06.2010, one pair, in a pastures among ameliorative channels;

- between Dyulevo and Svetlina, Burgas District (UTM square NG19) - two pairs found during the nesting seasons in 2008-2010;

- between Zimen and Glumche Villages, Burgas District (UTM square NH02), in a water basins of a pig farm - 24.06.2010, 14 ind., including juvenile birds;

- Krushevo Reservoir at Krushevo Village, Burgas District (UTM square NH00) - 7.06.2008, one pair with nine nestlings (Daskalova et al., in print).

- Eastern Rhodope Mountains

- small reservoir SW of Madzhari Village, Haskovo District (UTM square LG91) - 15.05.2017, one adult; 26.05.2017, one pair with one pullus, still not feathered;

- reservoir close to Ostar Kamak Village, Haskovo District (UTM square MG03) - April, 2018 and 2019 , one pair was observed, possible breeding attempt (Stoycho Stoychev, pers. communication);

- small reservoir close to Slavyanovo Village, Haskovo District (UTM square LG92) - April, 2019, one pair, possible breeding attempt (Stoycho Stoychev, pers. communication).

According to the existing published and newly obtained data on the breeding numbers of the species, the size of the Bulgarian population of the species could be expected to be between 80 and 120 breeding pairs. The ruddy shelduck was distributed in a total of 49 UTM squares, in 19 of them (38.8\%) the species was found for the first time after 2008. In 12 UTM squares the species was found before 2008 and confirmed later by us. In the rest 18 UTM squares the spe- cies was found before 2008 and not confirmed later by us or other authors.

Greece

According to the newest estimations, the breeding population of the ruddy shelduck in Greece has increased from 15-40 pairs in the 90-ties of XXth century to $60-80$ pairs in 2015 (Staneva \& Burfield, 2015). The species was found to nest mainly on some of the Aegean Islands as Limnos (at least 20-30 pairs), Lesvos (13-15 pairs), Kos (17-18 pairs) and Samos (10-12 pairs) (Heath \& Evans, 2000; http:// natura2000.eea.europa.eu/). In 2012, breeding of the species was proven also for Naxos Island, Cyclades (http://greekbirding.blogspot.com/2012/06/succesfull-breeding-of-ruddy-shelducks.html).

\section{Romania}

According to the data presented for the report under article 12 of the European Bird Directive (2008-2012), the ruddy shelduck was found during the breeding period in 58 ETRS 10x10 squares in Dobrudzha, an area between the Lower Danube River and the Black Sea coast, and in one ETRS square to the west of the Danube River, with a total population of 40-70 breeding pairs (http://pasaridinromania.sor.ro/Califar-rosu; https://circabc.europa.eu/sd/a/68b0ea7d-3a11-4a129eb4-4308c39d7de8/RO_A12NatSum_20141031. pdf). In the past its breeding numbers across the country were lower - 20-25 pairs (Vasiliu, 1968).

\section{Spring migration}

During the spring migration period (February-April), flocks of the ruddy shelducks were recorded as follows:

- Bugeac Lake (Romanian part of Dobrudzha) 20.02.2016, 27 ind.;

- Oltina Lake (Romanian part of Dobrudzha) 20.02.2016, 10 ind.;

- flooded meadows NE of Karnobat, Burgas District, Bulgaria - 3.04.2016, 35 ind. (Daskalova et al., in print);

- Poroy (Tankovo) Lake, Burgas, Bulgaria 31.03.2017, 34 ind.;

- Poroy (Tankovo) Lake, Burgas, Bulgaria 10.02.2019, 42 ind. 
Recent changes in the presence status and numbers of ruddy shelduck (Tadorna ferruginea) in the Eastern Balkans

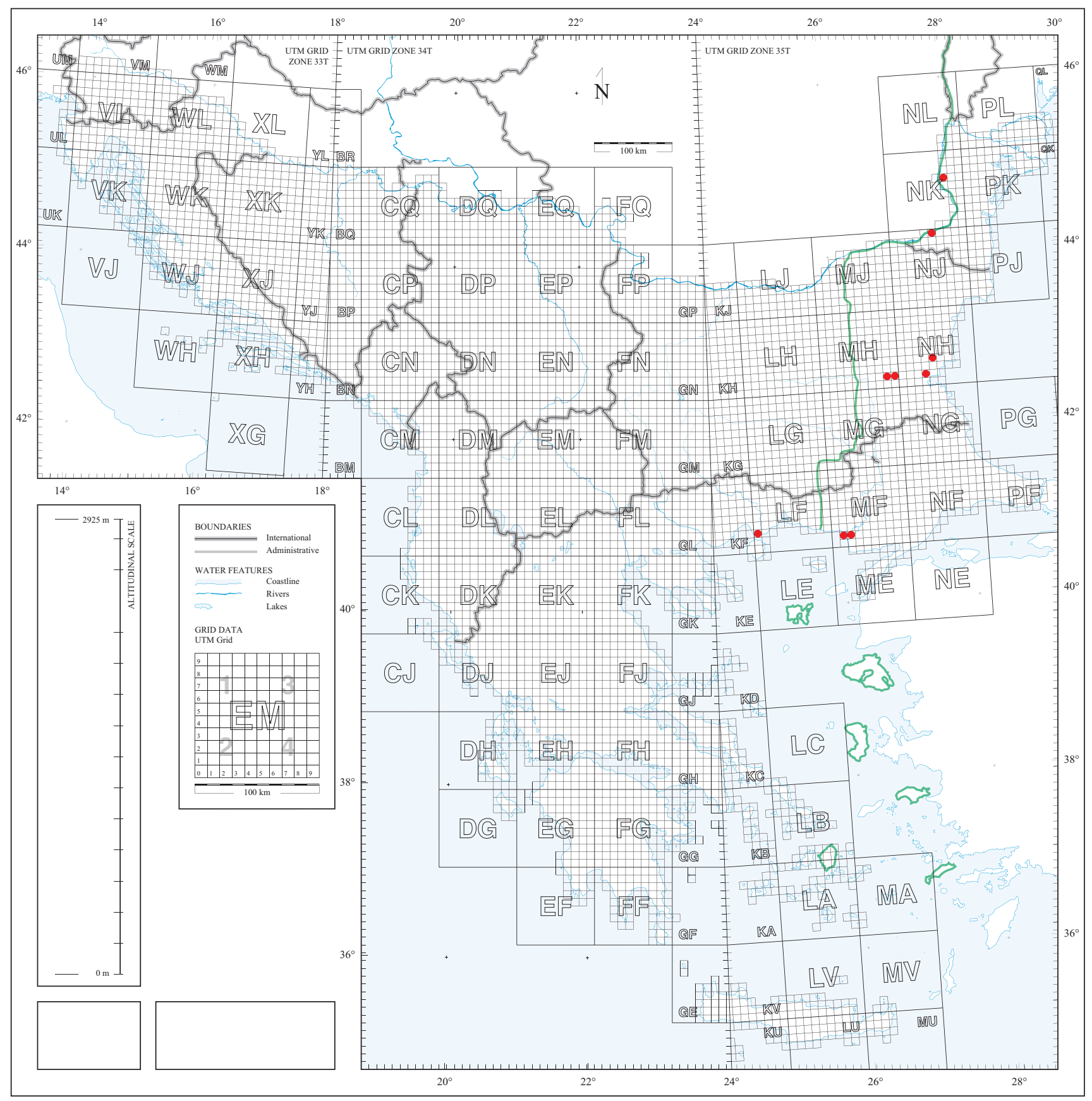

Fig. 2. Main areas of concentration of the ruddy shelduck (Tadorna ferruginea) on the Eastern Balkans during migration and wintering. Red dots show locations with more than 50 ind. recorded during one observation. Green line refers to the western border of the species breeding distribution on the Balkan Peninsula.

\section{Autumn migration}

During the autumn migration period (September-November), the species occurred in much bigger flocks than in spring. Main areas of concentration are shown on Fig. 2. In Bulgaria, they concentrated mostly in the salt Atanasovsko Lake close to Burgas. Ruddy shelduck's flocks were recorded as follows:

- Atanasovsko Lake, Burgas, Bulgaria-30.11.2017, 52 ind.;

- Atanasovsko Lake, Burgas, Bulgaria-16.10.2018, 261 ind.; 
Peter Shurulinkov et al.

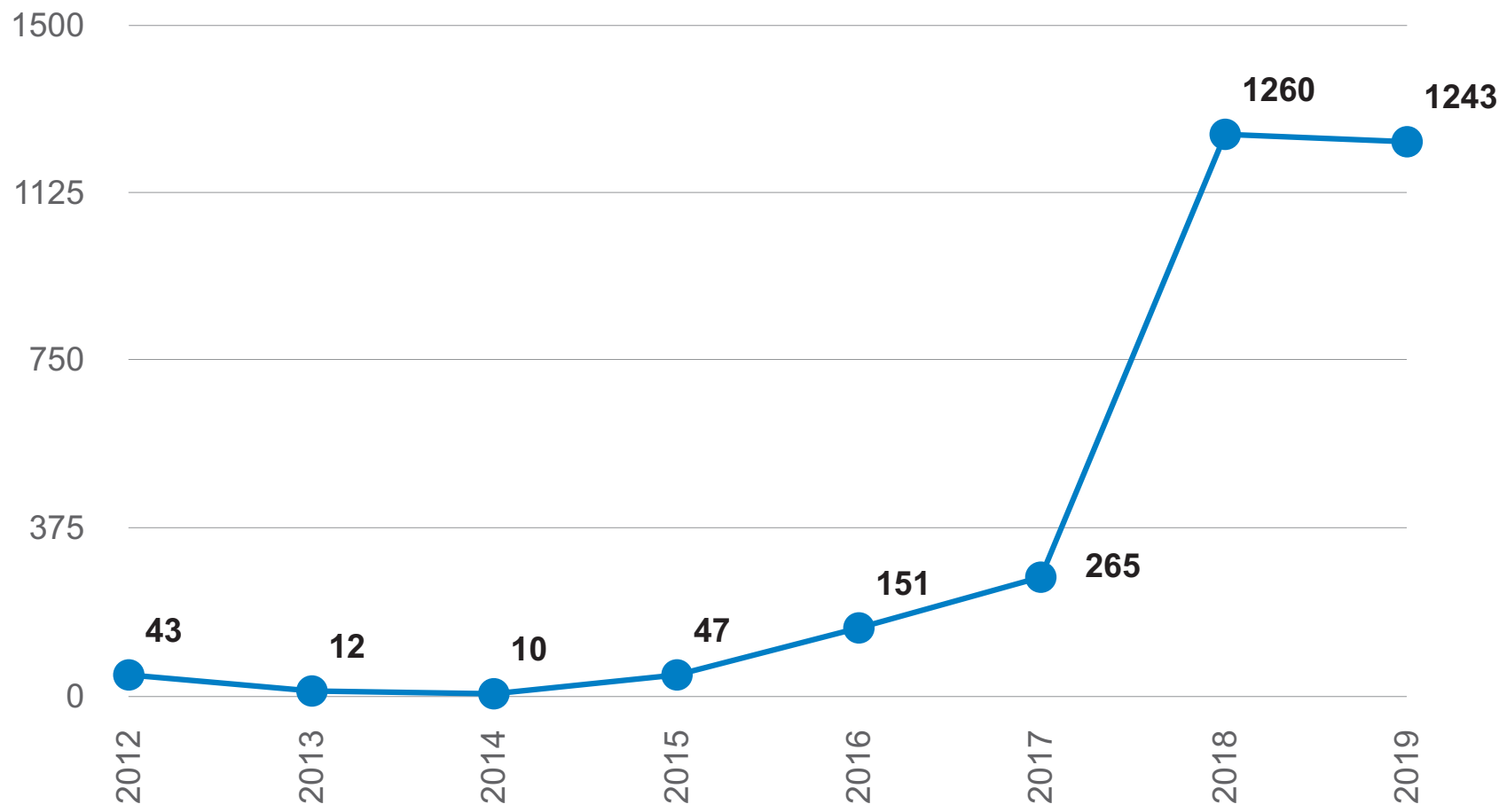

Fig. 3. Numbers of the ruddy shelducks (Tadorna ferruginea) counted during winter and migration (IX-III) in Bulgaria for the period 2012-2019 (all author's data are pooled, also data from ebird.org site are included).

- Atanasovsko Lake, Burgas, Bulgaria - 7.11.2018, 150 ind.;

- Atanasovsko Lake, Burgas, Bulgaria-17.11.2018, 445 ind.;

- Atanasovsko Lake, Burgas, Bulgaria - 5.09.2019, 170 ind.;

- Atanasovsko Lake, Burgas, Bulgaria-23.09.2019, 398 ind.;

- Lake Oltina, Romania - 22.09.2018, 400 ind. (ebird.org, Strahil Peev);

- Atanasovsko Lake, Burgas, Bulgaria-16.10.2019, 320 ind.

\section{Wintering}

Significant concentrations of wintering ruddy shelducks were recorded as follows (Fig. 2):

- Hazarlach Lake, to the east of Hirsova (Harsovo), Romanian part of Dobrudzha - 10.12.2017, 75 ind. in pastures to the east of the lake, together with 100 greylag geese (Anser anser), six shelducks (Tadorna tadorna) and one red-breasted goose (Branta ruficollis);
- Maritsa (Evros) River Delta (Greek part) 29.12.2015, 27 ind.; 30.12.2017, 1200 ind. came grouped in flocks of 10-100 birds from eastern direction in the evening (16:10-16:30 hrs) to spend the night in the pastures. Smaller flocks were reported there in the website ebird.org - on 12.01.2007, 230 ind. (Akis Gaitanakis); 6.01.2018, 540 ind. (Lefteris Kakalis) and 8.01.2019, 600 ind. (Dimitris Kokkinidis);

- Tserkovski Reservoir, Burgas District-8.12.2012, 29 ind; 28.12.2016, 81 ind. (Daskalova et al., in print);

- Krumovo gradishte, Burgas District, Bulgaria 30.01.2020, 103 ind., feeding on a rapeseed field;

- Poroy (Tankovo) Lake, Burgas, Bulgaria 14.01.2019, 56 ind.;

- Atanasovsko Lake, Burgas, Bulgaria-21.01.2019, 70 ind;

- Atanasovsko Lake, Burgas, Bulgaria-28.12.2019, 25 ind.

Solitary birds or small flocks (less than ten ind.) were observed during winter also at Mandra Lake, Burgas, Bulgaria (12.01.2019 - one ind.), Durankulak Lake, NE Bulgaria (ebird.org: 21.01.2019 - 
J.Borkman), at Balchik, NE Bulgaria (ebird.org: 21.01.2019 - one ind., D. Dallaire), Tekirgiol Lake, Constanta, Romania (ebird.org, 23.12.2018, Florin Chirila) and other locations.

We observed clearly positive overall trend of the numbers of the ruddy shelducks during migration and winter periods (2012-2019) for Bulgaria (Fig. 3). The major increase has started since 2016 year.

\section{Discussion}

The winter status of the species has changed significantly during the last ten years. Before 2008, the species was irregular wintering species in Bulgaria and regular but not numerous winter visitor in Northern Greece. In Burgas wetlands for the period 1996-2002 the maximal number of the species during winter was 5 ind., all at Atanasovsko Lake in 1999 (Dimitrov et al., 2005). In Maritsa (Evros) River Delta, winter numbers of the ruddy shelduck were reported to be 42-239 ind., according to the standard data form of the special protected area (SPA) Delta Evrou. (http://natura2000.eea.europa.eu/Natura2000/SDF. aspx? site $=$ GR1110006). Flocks of over 1000 birds as recorded in December 2017, in Maritsa River (Evros) delta (present study), have never been reported from the Balkan Peninsula. Nowadays, the ruddy shelduck can be qualified as regular winter visitor in Eastern Bulgaria and Eastern Romania and numerous wintering species locally in NE Greece.

Breeding numbers and distribution of the species also showed clear positive trend. Many of the formerly (in the period 1980-2000) abandoned areas have been reoccupied recently, such as many locations in NE Bulgaria. In the 80-ties of XX-th century the westernmost distribution of the ruddy shelduck in the Danube River Plain reached Nikopol and Brashlyanitsa, Pleven District (Boev, 1983; Botev \& Peshev, 1985). If the current positive trend continues, soon we could expect reoccupation also of these areas in the Central Danube River Plain. Additionally, some new areas were occupied recently by the species in SE Bulgaria, such as Yambol District and some locations in Haskovo District. Former data about the presence of the species in these regions are lacking or they do not refer to confirmed breeding but only to observations of pairs during the breeding period (Ilieva et al., 2007).

Recently, the numbers of the ruddy shelduck both during autumn and spring migration has increased.
Monthly monitoring at Burgas wetland complex for the period 1996-2002 recorded maximal counts of up to 29 ruddy shelducks during the spring migration and 15 ind. during autumn migration (Dimitrov et al., 2005). The highest number for that study was reached in June in Atanasovsko Lake - 35 ind. These numbers are significantly smaller as compared to the numbers recorded during the present study at the same locality. The greatest increase was recorded after 2016 and to a greater extent during autumn migration period.

However, the origin of the wintering and migrating ruddy shelducks across the Eastern Balkans remains unclear but we suppose that most of them come from the breeding populations of Ukraine and Southern Russia. Alternative hypothesis can be that flocks from Asia Minor also contribute to the observed picture, especially in forming the wintering population in Greece and SE Bulgaria.

What are the possible explanations of the increase of the numbers of the breeding, migrating and wintering ruddy shelducks on the Eastern Balkans? Increase of the breeding numbers and distribution of the ruddy shelduck throughout Eastern Balkans could be explained by some recent trends. Much milder and snowless winters in the region during the last 20 years allow many of the local birds to stay close to their breeding grounds. The increase of the birds spending winter in the Balkan states is obvious. Shorter migration distances decrease the chance of mortality of birds along the migration route. The rearing of captive ruddy shelducks at the Kalimok Biological Experimental Station and releasing them in the wild is another positive factor that, without any doubt, contributes to the species numbers, at least at local level.

For the increase of migration flocks using Balkan routes the main reason could be the increase of the breeding populations in the Balkan countries, Southwestern Russia, Ukraine and possibly in Asia Minor. During the period 1980-2000, there was a significant increase in the breeding population of the species in southern parts of European Russia, e.g. Stavropol District, Lower Volga River, Don River Valley and Western Manich Lake (Krivenko \& Vinogradov, 2001). In Ukraine some areas where the species has been extinct in the past, nowadays are being reoccupied again: for example Harkov Region, where the species started to breed after long period of extinction (since 1997) and its number reached 40-45 pairs in 2014 (Banik, 2014), but also in Lugansk Region and other parts of the country (Vetrov \& Litvinenko, 2014). The 
increase of the ruddy shelduck numbers and distribution in the western parts of its breeding range is explained with the shift of the traditional moulting sites from east (Kazakhstan) to west (in Southern Russia, Manich-Gudilo Lake system) because of drought of some key wetlands in Central Asia (Banik, 2014). The same author deny the possibility that the increase of the ruddy shelduck population is a consequence of the increase of the semi-wild population of "Askania-Nova" Nature Reserve (Ukraine) and gives a proof from the numerous ringing recoveries revealing that birds hatched there are almost entirely sedentary. The longdistance records of ruddy shelducks from that population are very rare and are reported from Russia, Azerbaijan and Georgia (Zubko et al., 2001).

\section{Acknowledgments}

We are grateful to our colleagues Stoycho Stoychev and Ivailo Angelov who sent us some additional data on the distribution and status of the ruddy shelduck.

\section{References}

Banik M. 2014 Expansion of Ruddy Shelduck (Tadorna ferruginea) in Kharkiv region in 1990-2010 and its possible causes. Birds of Severskovo Dontsa Basin 12: 184-200.

Bauer W., Helversen O., Hodge M., Martens J. 1969 Catalogus Faunae Graeciae. Thessaloniki, 182 pp.

BirdLife International 2004 Birds in Europe: population estimates, trends and conservation status. BirdLife International, Cambridge, UK, $374 \mathrm{pp}$.

BirdLife International 2015 European Red list assessment. Ruddy Shelduck (Tadorna ferruginea Pallas, 1764) http://datazone.birdlife.org/userfiles/file/Species/erlob/summarypdfs/22680003 tadorna_ferruginea.pdf https://circabc.europa.eu/ sd/a/68b0ea7d-3a11-4a12-9eb4-4308c39d7de8/ RO_A12NatSum_20141031.pdf.

Boev Z. 1983 Observations on the birds of the northern part of the Devetashko Plateau. Ornitologiceski Informacionen Bulletin 13/14: 31-36. (In Bulgarian)

Botev B., Peshev T. (eds) 1985 Red Data Book of People's Republic of Bulgaria. Vol. 2 Animals. BAS, 183 pp. (In Bulgarian)
Cramp S., Simmons K.E. (eds) 1977 The Birds of the Western Palearctic. Vol. I. Oxford University Press, 722 pp.

Daskalova G., Shurulinkov P., Angelov I., Petrov P. (In print) The Birds of Tundzha River Valley.

Dimitrov M., Michev T., Profirov L., Nyagolov K. 2005 Waterbirds of Bourgas wetlands. Results and evaluation of the monthly monitoring 1996-2002. Pensoft Publishers, Bulgarian Biodiversity Foundation, $159 \mathrm{pp}$.

[Cornell Lab of Ornithology] Ebird.org.

Hagemejer E., Blair M. (eds) 1997 The EBCC Atlas of European Breeding Birds: Their Distribution and Abundance. T \& A Poyser, London, 903 pp.

Handrinos G., Akriotis T. 1997 The Birds of Greece. Christopher Helm, A \& C Black, London, 336 pp.

Heath M., Evans M. (eds) 2000 Important bird areas in Europe. Priority sites for conservation. Vol. 2. Southern Europe. Birdlife International Conservation Series, Cambrigde, UK, 791 pp.

Hue F., Etchecopar R. 1970 Les oiseaux du Proche et du Moyen Orient. Paris, 948 pp.

Ilieva M., Zehtindjiev P., Kutsarov Y., Georgiev D. 2007 Ruddy Shelduck (Tadorna ferruginea). In: Iankov P. (ed.). Atlas of Breeding Birds in Bulgaria. Bulgarian Society for the Protection of Birds, Conservation Series, Book 10, Sofia, 94-95.

Kostadinova I. (ed.) 1997 Important Bird Areas in Bulgaria. BSPB, Conservation Series, Book 1, Sofia, 176 pp.

Krivenko V., Vinogradov V. 2003 Present status of the waterfowl resources in Russia and problems of their protection. Wetlands International, Moscow.

Michev T., Profirov L. 2003 Mid-winter numbers of Waterbirds in Bulgaria: Results from 25 Years of Mid-winter Counts Carried Out at the Most Important Bulgarian Wetlands (1977-2001). Pensoft, Sofia, $167 \mathrm{pp}$.

Nankinov D., Dutsov A., Nikolov B., Borisov B., Stoyanov G., Gradev G., Georgiev D., Popov D., Domuschiev D., Kirov D., Tilova E., Nikolov I., Ivanov I., Dichev K., Popov K., Karaivanov N., Todorov N., Shurulinkov P., Stanchev R., Aleksov R., Tzonev R., Ivanov S., Marin S., Staikov S., Nikolov S., Dalakchieva S., Nikolov H. 2004 Breeding totals of the ornithofauna in Bulgaria. Green Balkans, Plovdiv, 32 pp.

Nankinov D., Simeonov S., Michev T., Ivanov B. 1997 The Fauna of Bulgaria. Vol. 26. Aves. Part 2. Publ. Houses Marin Drinov and Pensoft, 427 pp. 
SOR. Pasari din Romania. http://pasaridinromania. sor.ro/Califar-rosu.

Shurulinkov P., Cheshmedzhiev S., Daskalova G., Dinkov H., Kirov K., Hristov I., Kutsarov Y., Koev V., Mihov S. 2019 Recent data on the distribution and numbers of the water birds in the wetlands along the Bulgarian-Romanian section of the Danube River. In: Shurulinkov P. et al. (eds) Biodiversity of the Bulgarian-Romanian section of the Lower Danube. Nova Publishers, New York, 341-374.

Staneva A., Burfield I. (eds) 2015 European Birds of Conservation Concern. https://www.birdlife. org/sites/default/files/attachments/European \%20 Birds \%20of\%20Conservation\%20Concern_Low. pdf.

Vasiliu G.D. 1968 Systema Avium Romaniae. Alauda (suppl.) Paris, 120 pp.
Vetrov V., Litvinenko S. 2014 Actual status of the Ruddy Shelduck (Tadorna ferruginea) in Lugansk region. Birds of Severskovo Dontsa Basin 12: 159-169.

Zehtindjiev P., Bogdanova M., Bedev K. 2015 Ruddy Shelduck (Tadorna ferruginea). In: Golemansky et al. (eds) Red Data Book of the Republic of Bulgaria. Vol. 2 Animals. BAS \& MOEW, Sofia, p. 73.

Zubko N., Havrilenko V., Semenov N. 2001 Restoration of the Ruddy Shelduck Tadorna ferruginea population in "Ascania Nova" nature reserve (Southern Ukraine). Acta Ornithologica 36 (1): 97-100. 